\title{
The Changing Pursuit of Happiness
}

\author{
Steven N. Handel
}

\section{The Declaration}

T $\mathrm{n}$ the United States, our first statement of national identity was perhaps our most influential. The 1776 Declaration of Independence argues that all people have "unalienable Rights, that among these are Life, Liberty and the pursuit of Happiness." The "pursuit of happiness" is a remarkable concept, involving an entire universe of actions: individual goal setting free from family status or financial state; the possibility to choose and then learn one's profession; and defining your private affections, from how you spend time to who shares that time with you. We are a nation where happiness is determined in each person's heart, not by consensus or decree, and this leads to the animated and wonderful diversity that is the public life of the country. The pursuit of happiness foundation of our country's social life is, we believe, under attack today . . . by climate change. What can restoration ecologists do to help?

\section{The Climate}

The recent National Climate Assessment is our best summary of what the physical world will be for the biota we are trying to restore. The many changes in temperature regimes, sea level rise, storm frequency, seasonality, and shifting biotic zones are nightmares for practitioners seeking sustainable habitats and the services they supply.

We humans are part of the biota also, of course. These enormous climate changes are already having direct effects on public health problems. The indirect effects of flooding, storm patterns, and sea level rise add other layers of social disruption as well as major impacts to restoration ecology projects. Recent studies of the warming Earth have shown that there is not homogeneous change across geographic regions. The velocity of climate change is impacted by local topography and geographic position. The velocity differs between marine and terrestrial areas. Warming is a mosaic of change with different areas heating at different rates. The biotic zones shift and the velocity of these movements

Ecological Restoration Vol. 32, No. 3, 2014

ISSN 1522-4740 E-ISSN 1543-4079

(O2014 by the Board of Regents of the University of Wisconsin System. are irregular. Restoration science in this shifting mosaic of conditions is terribly difficult.

We lobby to public officials that the ecological services of restored habitats are vital to human communities. Whatever your personal pursuit of happiness, you rely on these ecological services to smooth your path forward in life. As climate changes, the pursuit becomes a steeplechase of obstacles, with episodic flooding, drought, heat waves, and storm events interfering with our dreams.

\section{The Role of Intervention}

In the changing physical world, elements of the biosphere move, adapt, or perish. Restoration science has become cautious knowing that the targets we choose for restoration today may be inappropriate in the not distant future. For many of us the goal of our professional pursuit of happiness is a project that succeeds. We would not like that success erased in a few decades by the stress of climate change. Interesting new approaches are being tried all over the world to address these issues, including assisted migration of species, consideration of novel ecosystems for stressed areas, and modification of provenance types to be used in a project. Development of migration corridors at local or regional scales may permit movement of some plant and animal species to occur to keep pace with the velocity of climate change. Each of these practices may play a role in habitat persistence and keeping our professional pursuit of happiness moving forward.

In the Broadway show, "Avenue Q," an actress sings, "There's a fine, fine line between reality and pretend. . . . There's a fine, fine line between love and a waste of time." Our interventions may be pretend, may even be a waste of time in this world of climate unknowns, but who are we to tell you not to work at what you love; your pursuit? At least we can give you more tools and knowledge, in the pages of this journal, to smooth the path forward.

\section{The Sublime}

The concept of the sublime expresses our passion for the extraordinary, inspiring, even spiritual experience. This drives us towards our goals. Many practitioners and volunteers in restoration ecology are not motivated by a profit or a financial balance sheet, but by affection for nature as 
it nurtures our lives. Today, many people seek out natural places for a moment of happiness. In a changing, warming world, those places may be gone, and too many people do not have the means to travel to a replacement area for those moments of happiness or inspiration. Think of a poor family, with young children, who rely on a nearby woodland or seashore to find some happiness. If restoration science and action can find ways to replace those special areas with new ones for all our people, perhaps that too can be the sublime in our social contract.

It's often been said that the Constitution only guarantees you the right to pursue happiness. You have to catch it yourself. Well, this right wasn't in the Constitution, it was in the Declaration, and the guarantee is inalienable, inherent to our humanity, not conditional on some government document. Regardless, each person's pursuit can be thrilling and gives great meaning to a life. With the climate velocity zipping along, the pursuit must keep pace, and our restoration work had better switch to a higher gear!

\section{Recommended References}

Burrows, M.T., D.S. Schoeman, L.B. Buckley, P. Moore, E.S. Poloczanska, K.M. Brander, C. Brown, J.F. Bruno, C.M. Duarte, B.S. Halpern, J. Holding, C.V. Kappel, W. Kiessling, M.I. O’Conner, J.M Pandolfi, C. Parmesan, F.B. Schwing, W.J. Sydeman and A.J. Richardson. 2011. The pace of shifting climate in marine and terrestrial ecosystems. Science 334(6056):652-655.

Loarie, S.R., P.B. Duffy, H. Hamilton, G.P. Asner, C.B. Field and D.D. Ackerly. 2009. The velocity of climate change. Nature 462:1052-1055.

Patz, J.A., D. Campbell-Lendrum, T. Holloway and J.A. Foley 2005. Impact of regional climate change on human health. Nature 438:310-317.

U.S. Global Change Research Program. 2014. National Climate Assessment. nca2014. globalchange.gov/.

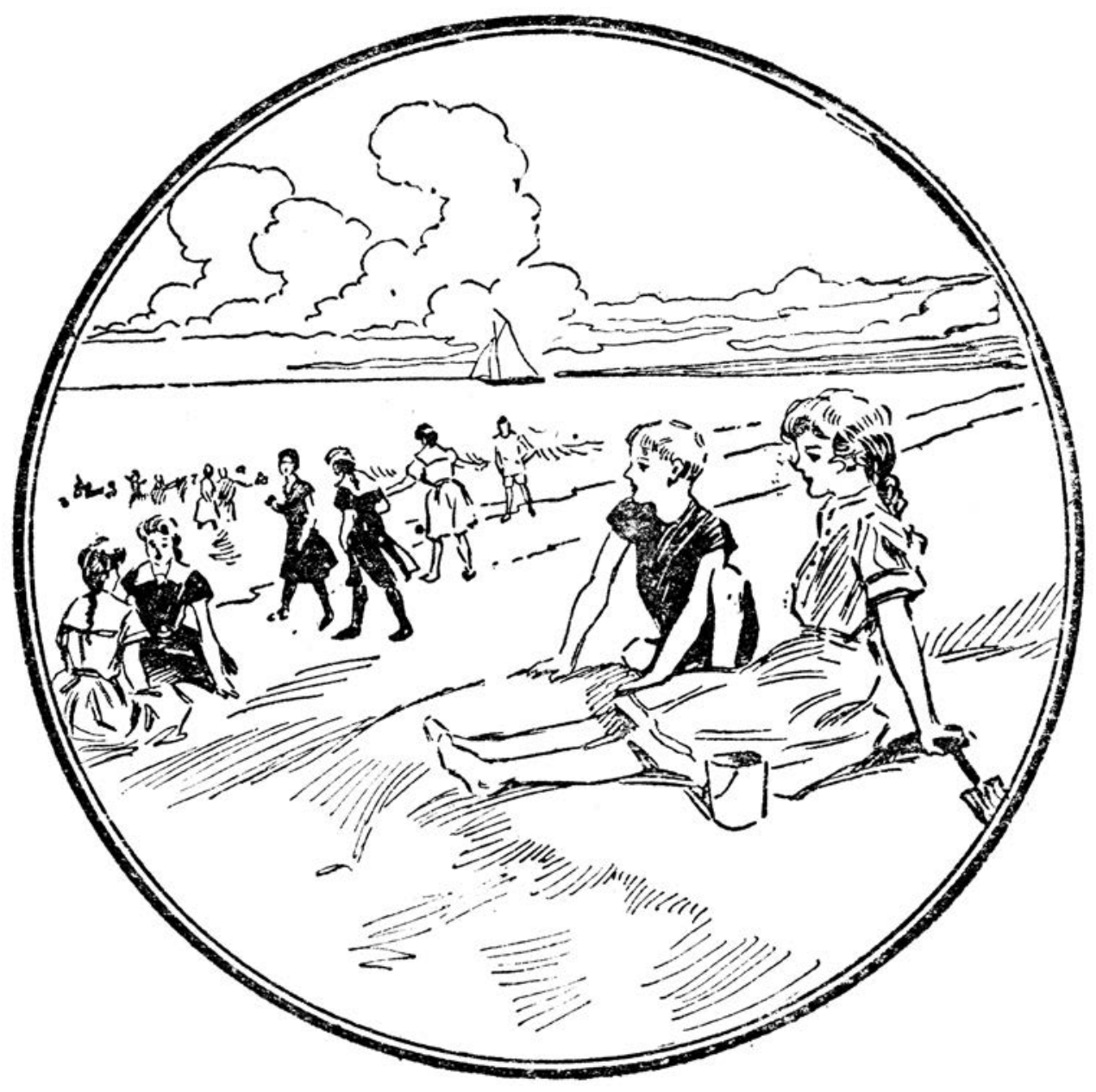

St. Nicholas, M.M.D. 1907. An Illustrated Magazine for Young Folks Volume XXXIV. New York, NY: The Century Co. The Florida Center for Instructional Technology, fcit.usf.edu. 